EMBRYARIDDLE
Aeronautical University

SCHOLARLY COMMONS
International Journal of Aviation, Aeronautics, and Aerospace

\title{
A Tale of Two Airlines: A Comparative Case Study of High-Road versus Low-Road Strategies in Customer Service and Reputation Management
}

\author{
Donna Roberts \\ WW/Social Sciences \& Economics, rober596@erau.edu \\ John C. Griffith \\ Embry-Riddle Aeronautical University, griff2ec@erau.edu
}

Follow this and additional works at: https://commons.erau.edu/ijaaa

Part of the Business Commons, and the Social and Behavioral Sciences Commons

\section{Scholarly Commons Citation}

Roberts, D., \& Griffith, J. C. (2019). A Tale of Two Airlines: A Comparative Case Study of High-Road versus Low-Road Strategies in Customer Service and Reputation Management. International Journal of Aviation, Aeronautics, and Aerospace, 6(2). https://doi.org/10.15394/ijaaa.2019.1317

This Article is brought to you for free and open access by the Journals at Scholarly Commons. It has been accepted for inclusion in International Journal of Aviation, Aeronautics, and Aerospace by an authorized administrator of Scholarly Commons. For more information, please contact commons@erau.edu. 
A Tale of Two Airlines: A Comparative Case Study of High-Road versus Low-Road Strategies in Customer Service and Reputation Management

\section{Cover Page Footnote}

We would like to acknowledge the support of Embry Riddle Aeronautical University for providing funding for travel and software in support of this research. 


\section{Introduction}

This research represents an in-depth comparative case study highlighting the differences in marketing strategies, and customer service models between American low-cost carrier Southwest Airlines and European low-cost carrier Ryanair. Analysis focused on the differing brand personalities of the two airlines, particularly with regard to customer service and its relationship to customer satisfaction and overall corporate success from the early days of these organizations through 2013. Southwest Airlines is a budget U.S. airline that prides itself on customer service. Its internal branding provides specific behaviors to ensure employee buy-in to its friendly culture. The focus on respect, concern and a caring attitude toward all customers is a hallmark of the Southwest Airlines internal marketing strategy. This corporate culture appears to build employee motivation resulting in higher levels of quality service, customer satisfaction and higher profitability. Southwest has turned a profit every year since 1973; the only US airline to do so, (Czaplewski, Ferguson, \& Milliman, 2001; Schleckser, 2018). Ryanair is a budget European airline that ignores typical customer service. It can be easily argued that Ryanair takes the opposite approach to customer service in order to keep costs down. Customers expect low fares but also understand that they will receive a low level of customer service (Ozcelik \& Findikli, 2014).

\section{Research Question}

Is there any difference between how Southwest (high customer expectations) and Ryan Air (low customer expectations) are evaluated by customers? In other words, will differences in the perception of customer service between the two airlines be negated by preconceived notions of service?

\section{Purpose}

The purpose of this case study research is to understand the phenomenon of airline customer expectations and perceived customer satisfaction between two low-cost airlines informed by the Expectation Confirmation Theory. The findings will provide insights and a better understanding about airline marketing models can be used to manage customer expectations in order to provide greater customer satisfaction.

The theoretical framework of this study revolves around the connection of Expectation Confirmation Theory with customer perception and behavior in the airline industry. This study compares two airlines with opposite approaches to customer service thereby filling an important gap in current aviation customer service literature. 
Ryanair would be judged less stringently on customer service due to the low initial expectations. Conversely, Southwest would be judged more rigorously on the same criteria, based on its initial high expectations.

\section{Literature Review}

Southwest Airlines - "The Somebody Else Up There Who Loves You" Ryanair Director of Customer Service - "We're the airline everyone loves to hate"

\section{Customer Service and Business Success}

Expectation confirmation theory (also known as expectation disconfirmation theory) refers to a cognitive theory that is applied to consumer behavior, particularly post-purchase satisfaction. The theory depends upon the interaction between expectations, perceived performance and the confirmation, or alternatively the disconfirmation, of beliefs.

Originally developed by Richard Oliver (1977), the basic tenets of the theory posit that: 1) Positive disconfirmation occurs when a product outperforms expectations which yields a result of post-purchase satisfaction; and 2) Negative disconfirmation occurs when a product fails to meet expectations, which yields a result of post-purchase dissatisfaction (Oliver, 1980; Spreng, MacKenzie, \& Olshavsky, 1996). This process is further illustrated in Fripp's Disconfirmation Model of Customer Satisfaction in Figure 1 below. 


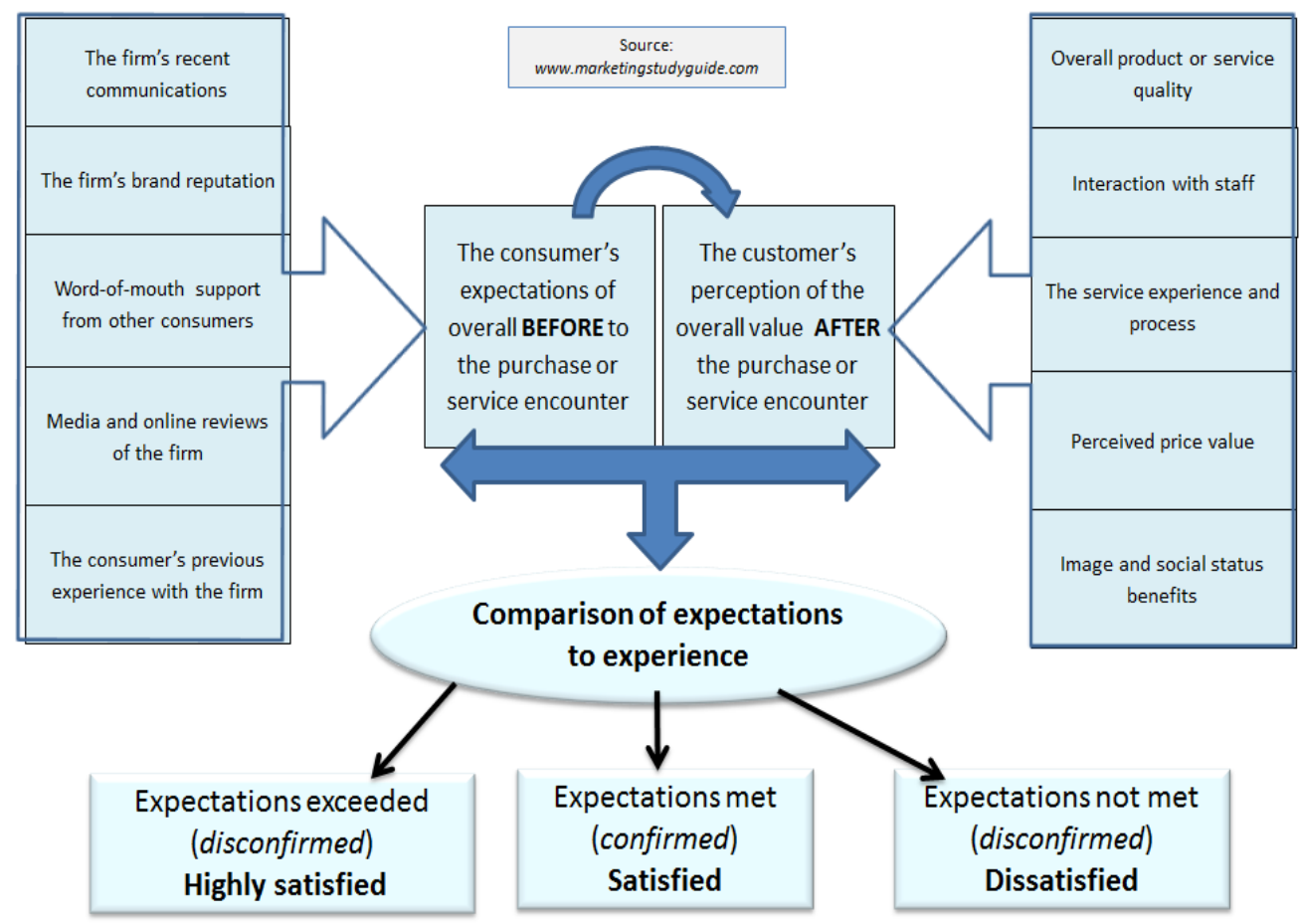

Figure 1. The Disconfirmation Model of Customer Satisfaction. Customer impressions from the left side of the model and company inputs from the right have an impact on the center two boxes identifying expectations before and after the purchase or service encounter. These expectations are compared to the actual experience resulting in highly satisfied, satisfied or dissatisfied customer. F. Fripp, p. 1 Customer Satisfaction, Introductory Concepts, Services Marketing Models.

As shown above, expectations, rather than an objective standard of performance, are the major determinants of consumer satisfaction. Thus, in this model, two parity products could deliver a similar level of customer service and be judged differently based upon differing initial expectations. Alternatively, one product/service could, by objective measures, underperform as compared to another product/service, and yet render higher reported customer satisfaction, again based on the comparison of differing initial expectations and the degree to which these expectations were met or not met.

Applying this theory to a comparison of Ryanair and Southwest one must take into account the very different expectations that each airline sets up via their respective marketing and consumer communication. Intuitively, one would reasonably expect a highly customer-centric approach, like that of Southwest, to yield overwhelmingly positive customer response, while the highly antagonistic approach embraced by Ryanair would yield consistently poor consumer satisfaction rates. However, the expectation confirmation theory suggests that these effects will 
be mitigated by the initial expectations each airline sets as its baseline. Southwest promises to deliver exceptional customer service along with low fares, while Ryanair sets up expectations for a low level of service in exchange for their low fares. Thus, the theory holds, that the consumer reaction to Southwest will not be quite as high as perhaps merited, because they set their own bar of service so high, while conversely the reaction to Ryanair will perhaps not be as negative as one might anticipate, simply because they put forward lower expectations.

While it is unlikely that just setting low expectations will completely eradicate objective standards for good versus bad customer relations or yield a good rating for poor service, the expectation confirmation theory emphasizes the importance of perception in framing judgment and appraisal in consumer behavior. It provides at least a partial explanation for why, though often criticized, Ryanair has been able to continue with seemingly negative customer relations and yet remain popular and profitable.

In competitive industries, customer service has long been lauded as a necessary component of organizational success and a means of competitive advantage (Anderson, Fornell, \& Lehmann, 1994, Luo \& Homburg, 2007; Yeung, Ging, \& Ennew, 2002). It has been heralded as the holy grail of enlightened business policy and credited for resulting in subsequent business success. Supported by icons of entrepreneurship and retail including Harry Gordon Selfridge, John Wanamaker, and Marshall Fields, the directive caveat emptor ("let the buyer beware") was replaced by "the customer is always right" thus ushering in the dogged pursuit of customer satisfaction and acquiescence. Notwithstanding this plethora of empirical and anecdotal evidence supporting the relationship between customer satisfaction and commercial business success, Ryanair adopted an antagonistic attitude with customers and still enjoyed unprecedented success, while Southwest Airlines lagged behind despite their consistent customer-centric focus.

Keeping fickle and indecisive customers happy can represent a costly and Sisyphean goal - one that could potentially run counter to the fundamental mission and objectives of a company. Thus, the question becomes, to what level should customer satisfaction be pursued and how does this translate into practical customer service policy and procedure?

The purpose of this study was to measure the specific perceptions of Ryanair and Southwest Airlines to determine how expectations - expectation of low customer service in the case of Ryanair and expectations of high levels of customer service in the case of Southwest Airlines - impacted how customers rated the respective airlines in survey questions and ultimately to consider how that view of customer service impacted the success of the business. 


\section{Ryanair and Southwest - The Same ... But Different}

Despite being continents apart, Ryanair and Southwest Airlines have frequently been held up as the European and American counterparts of the low-cost market. Views differ on whether these two contenders represent parity products in their respective markets, or if key differences make them into the proverbial apples vs. oranges, incapable of meaningful comparison. Whether or not you consider them worthy of comparison is largely due to how, and where, you choose to focus the microscope of analysis.

Certainly, they exist in a different cultural milieu and operate in somewhat different regulatory environments. But none of these differences precludes a comparison based on the very human reaction to a level and manner of treatment or interpersonal interaction. Or, conversely, if it does, then perhaps it is those very differences that are the largest point of interest.

Table 1 depicts a comparison between Ryanair and Southwest Airlines on some key characteristics. Note that given the timeframe of this study, these details reflect information as of 2012 (McClure, 2013). 
Table 1

Vital Statistics Comparison - Ryanair vs. Southwest Airlines - from 2012

\begin{tabular}{|c|c|c|}
\hline CRITERIA & RYANAIR & SOUTHWEST \\
\hline Date Established & 1985 & 1971 \\
\hline Operational Region & 29 Countries & 41 States (USA) \\
\hline Number of Destinations & 180 & 97 \\
\hline Fleet Size & 302 & 640 \\
\hline Number of Daily Flights & 1,600 & 3,700 \\
\hline Non-stop Flights & All & 570 \\
\hline Average Flight Distance & 771 miles & 708 miles \\
\hline $\begin{array}{l}\text { Average One-Way Flight } \\
\text { Cost }\end{array}$ & US \$60 & US \$159 \\
\hline Most Common Aircraft & $\begin{array}{l}\text { Boeing 737-800 } \\
\text { Used exclusively }\end{array}$ & $\begin{array}{l}\text { Boeing 737-300 } \\
6 \text { different aircraft used }\end{array}$ \\
\hline $\begin{array}{l}\text { On-Board Customers } \\
\text { (2012) }\end{array}$ & 80 million & 134 million \\
\hline $\begin{array}{ll}\text { Direct Booking via } \\
\text { Airline Website }\end{array}$ & $99 \%$ & $81 \%$ \\
\hline $\begin{array}{l}\text { Passengers Redeeming } \\
\text { Award Flights }\end{array}$ & 0 & 4.5 million \\
\hline $\begin{array}{l}\text { Cost per Available Seat } \\
\text { Mile (CASM) (2012) }\end{array}$ & US $\$ 0.07$ & US $\$ 0.13$ \\
\hline Total Net Profit (2012) & US \$ 679 million & US \$ 421 million \\
\hline
\end{tabular}

Note: Statistical comparisons. Adapted from "Polyester Airlines: Ryanair vs.

Southwest," by G. McClure, 2013. Retrieved from: www.flightfox.comData.

\section{Southwest Airlines . . . From a Cocktail Napkin to an Empire}

In 1967, after Rolin King proposed a simple three city route to Herb Kelleher, sketching out the map between the Texas cities on a cocktail napkin, Southwest Airlines was launched in 1971 to serve the inter-city routes in the Dallas/Ft. Worth - San Antonio - Houston triangle. By 2003, it had grown to approximately 35,000 employees serving 30 states with approximately 2,800 flights per day (www.southwest.com).

From its grassroots beginnings, Southwest has been heralded as an innovative pioneer. In its 1993 annual report, the Department of Transportation noted, "The principal driving force behind dramatic fundamental changes that have occurred and will occur in the U.S. airline industry over the next few years is the 
dramatic growth of low-cost Southwest Airlines" (Bennett \& Craun, 1993). The report cited Southwest's business model, including its innovative pricing structure, short-haul service routes, aggressive expansion, and low operating costs, as key features of its success. Southwest consistently ranks at the top of the various quality measures-including on-time performance, baggage handling, and customer complaints (Friedberg \& Friedberg, 1997). Their quality and productivity continue to serve as benchmarks for the industry.

While industry measures typically evaluate the airline on its key financial indicators, the company itself emphasizes people as its core focus. Southwest's values and their focus on customer service is explicitly stated in their longstanding mission statement, which is readily available to the public on their website:

The mission of Southwest Airlines is dedication to the highest quality of Customer Service delivered with a sense of warmth, friendliness, individual pride, and Company Spirit.

(Southwest Airlines, 2018)

Similarly, their stated company purpose, reflects these values as well, proclaiming,

Our Purpose

To connect People to what's important in their lives through friendly, reliable, and low-cost air travel.

(Southwest Airlines, 2018)

Likewise, the prominent quote on their website speaks in the same vein, "Our people are our single greatest strength and most enduring long-term competitive advantage," Gary Kelly, CEO Southwest Airlines (Southwest Airlines, 2018).

\section{Ryanair ... Inspired by Southwest, But Without All the Love}

Ryanair was founded in 1984 (originally as Danren Enterprises) and began operations in 1985. In the late 1980s, Tony Ryan, facing crisis with his familyowned carrier, sought the advice of his financial advisor, Michael O'Leary, who, in his characteristic brash manner, advised, "Shut the bloody thing down" (Michaels, 2000). Instead however, O'Leary agreed to take over the operations of the airline, but only after a trip to Dallas, Texas to observe the operations of the highly successful Southwest Airlines. In one of his rarely heard compliments O'Leary referred to the iconic Southwest CEO as, "An absolute ... genius. Kelleher was the one who brought air travel within the pockets of average people" (The Courier-Journal, 2000, p. 1).

It was at this point that Ryanair became the low-cost, no-frills, and profitable airline that we know today. In O'Leary's words, "We're Europe's 
Southwest Airlines" (Menza, 2013, para. 4). Despite adopting the Southwest model, Ryanair's more focused and business-oriented mission statement stands in stark contrast to Southwest's consumer-centric one.

Ryanair's mission is to offer low fares that generate increased passenger traffic while maintaining a continuous focus on cost containment and efficiency operation. Ryanair's objective is to firmly establish itself as Europe's leading low-fares scheduled passenger airline.

(Ryanair, 2005)

\section{Publicity, Advertising, and Brand Image}

Despite having similarities in many aspects of their business operations, it is the public image, and the tactics employed in the pursuit thereof, that represents the area where Ryanair and Southwest differ most prominently. Southwest has followed the more conventional route, choosing a mild-mannered and inoffensive public relations orientation, albeit sprinkled with a dose of their own quirky humor. Ryanair, instead, has frequently engaged in controversial advertising and public statements in what O'Leary admits is a deliberate action to generate free publicity.

From its inception in Dallas Love Field, Southwest has capitalized on a love theme, incorporating it in their stock symbol (LUV) as well as their slogans and logos. Southwest routinely employs humor in their advertising, but it steers away from the political and controversial into the silly, ironic, and corny. Even their arguably sexist ads, particularly those of the 1960s, have a more slapstick mainstream feel than their more risqué and potentially offensive Ryanair counterparts. See Appendix A for a sample of Southwest and Ryanair advertising.

Just as the name Herb Kelleher is synonymous with the Southwest image, so too is Michael O'Leary inextricably linked to the brand personality of Ryanair. These larger-than-life personalities comprise the good, the bad, and the ugly of their respective companies. Each is flamboyant, but in their own unique way - Kelleher more goofy and avant-garde, while O'Leary more crass and obnoxious. Yet even O'Leary's offensiveness has been met with a cavalier, almost boys-will-be-boys kind of sentiment. He is the CEO consumers, competitors, and regulators alike, love to hate. And this sentiment naturally extrapolates to feelings about the airline. As noted in the Wall Street Journal Europe (Michaels, 2000), "Passengers grumble that flying Ryanair is like riding a bus, although they're doing it by the busload."

\section{What They Say About Themselves and Their Customers}

Ryanair's flamboyant CEO, Michael O'Leary is notorious for critical and often vulgar outbursts toward the industry, competitors, and even customers, which are inappropriate and unprofessional at best, and litigious at worst. His flippant, 
unapologetically harsh, and arguably offensive comments have become an integral part of the brand personality. Among his many outbursts to the press, he states:

On turbulence: "If drink sales are falling off, we get the pilots to engineer a bit of turbulence. That usually spikes up the drink sales."

On charging passengers to use the toilet: "One thing we have looked at is maybe putting a coin slot on the toilet door so that people might actually have to spend a pound to use the loo in the future. If someone wanted to pay $£ 5$ to go to the toilet, I would carry them myself. I would wipe their bum for a fiver."

On the in-flight experience: "Anyone who thinks Ryanair flights are some sort of bastion of sanctity where you can contemplate your navel is wrong. We already bombard you with as many inflight announcements and trolleys as we can. Anyone who looks like they are sleeping, we wake them up to sell them things."

On upright seating: "I'd love to operate aircraft where we take out the back ten rows and put in hand rails. We'd say if you want to stand, it's five euros. People say 'Oh but the people standing may get killed if there's a crash'. Well, with respect, the people sitting down might get killed as well."

On low fares: "If you can't find a low fare on Ryanair, you're a moron."

On customer service: "People say the customer is always right, but you know what? They're not. Sometimes they are wrong and they need to be told so."

On apologies: "Are we going to say sorry for our lack of customer service? Absolutely not."

On passengers who forget to print their boarding pass: "We think they should pay 60 Euros for being so stupid."

On refunds: "You're not getting a refund, so **** off. We don't want to hear your sob stories. What part of 'no refund' don't you understand?" (Daily Telegraph, 2012). 
These are a stark contrast to the sentiment embodied in the words of Southwest's Herb Kelleher:

"A company is stronger if it is bound by love rather than by fear."

"Leading an organization is as much about soul as it is about systems. Effective leadership finds its source in understanding."

"The essential difference in service is not machines or 'things.' The essential difference is minds, hearts, spirits, and souls."

"When someone comes to me with a cost saving idea, I don't immediately jump up and say yes. I ask: what's the effect on the customer?"

(Brown, 2016).

\section{What Others Say About Them}

Ryanair's reputation for poor customer service has been noted throughout various media. The Economist wrote that the airline's "cavalier treatment of passengers" has given Ryanair "a deserved reputation for nastiness" (2007, para. 7). In 2013, Which? Magazine conducted a survey on customer service across the UK's biggest brands. They measured staff's knowledge, attitude, and ability to deal with issues. Ryanair scored two stars (of a possible five) for each category, producing an overall rating of 54\% the lowest (by 5\%) of all 100 firms included in the survey. Ryanair responded to the report by retorting, "The survey conclusively proves that Which? Magazine hasn't got a clue about what air travel consumers actually do, because they're too busy booking Ryanair's low fare, on-time flights to waste time filling in Which? Magazine's tiny surveys" (Smith, 2013; Which?, 2013).

Likewise, Siegel+Gale surveyed more than 12,000 customers in eight countries and reported that Ryanair was "the second worst brand in the world," based on criteria such as ease of customer use of a company's products, services, interactions and communications. O'Leary again responded similarly, posing the question, "If we're the worst performing brand in the world, why are we the biggest international airline in the world? Why are we the most profitable airline? We have rising load factors, rising traffic, rising growth and rising profits, meanwhile some bunch of nobodies does a reputational survey that says for some reason we're unsuccessful. The proof is what consumers do, not what some silly study says. I have 87 million people this year who say that survey is wrong" (Magrath, 2014). 
While the popular press embraces these customer surveys, O'Leary raises a valid point and equally valid questions. The 2013 figures from the Civil Aviation Authority indicated that the agency received 35 complaints about Ryanair per million passengers, compared with 174 for US Airways and 139 for Virgin Atlantic (Porter, 2014). Thus, while its customer service reputation is certainly not stellar, it is not the worst in the industry, and despite the negative publicity, the airline thrives, often when others, even those with better customer service indicators, do not.

This counter-intuitive phenomenon has not gone unrecognized in the industry. "Ryanair is very clear that its brand of customer experience is not founded on service. The company wants to be known as the go to airline for low fares. It targets customers for whom price is the dominant purchase driver. The airline is laser focused in executing a business model that enables it to deliver low fares to high volumes of passengers. It has done this very successfully and, in the process, expanded the low-cost market more profoundly than any other airline in Europe" (Gould, 2018).

Once again, in contrast, Southwest has enjoyed a kinder, gentler portrayal in the media and more positive feedback with regard to its customer service reputation. According to the Temkin Experience Ratings, an annual customer experience benchmark of companies based on a survey of 10,000 consumers. Southwest has earned the highest score for an airline every year since the ratings began in 2011 (Gould, 2018). Southwest Airlines also earned the \#10 ranking in the 2012 Wall Street Customer Service Hall of Fame. Specifically, Southwest's customer service ratings earned a 33.9\% "Excellent" rating and only 3.3\% "Poor." (Webb-Mrogan, 2017). Similarly, Southwest continually ranks high on Fortune's annual list of World's Most Admired Companies (often the only commercial airline ranking among the top 10) (PR Newswire, 2018).

\section{The Bottom Line}

Airlines, however, are ultimately businesses, and, as such, must concern themselves with financial health and sustainability. With respect to comparable profitability for 2012 ,

- Ryanair was the most lucrative European budget airline, profiting \$679 million dollars (€503 million) in 2012 .

- Southwest Airline's profit was \$421 million dollars, \$258 million (or 40\%) less than Ryanair.

(McClure, 2013, para. 5, 7).

While profit represents a highly complex culmination of many factors factors that are affected by the various differences in the diverse operating environments of these two airlines - it is nonetheless the proverbial bottom line. In 
the end, it is the measure of success that many consider the only one of true importance for any business. So, how is it that a company that blatantly and unapologetically breaks the rules of customer relationship management could be more profitable than one that wholeheartedly embraces those tenets?

Addressing just this question, The Economist (2007, para. 3) wrote,

That is the paradox of Mr. O'Leary's Ryanair. It is hugely successful. It has brought flying within the reach of people of the most limited means. It has helped to change the economic prospects of neglected parts of Europe by bringing passengers and their money to underused provincial airports. But at the same time Ryanair has become a byword for appalling customer service, misleading advertising claims and jeering rudeness towards anyone or anything that gets in its way.

When posed the question, "If Customer Experience is so important, how do you explain the success of Ryanair?" various customer experience consultants responded:

"This is a perfect illustration of a business understanding what's important to the customer. Ryanair knows that it's service can be left wanting in certain areas but in terms of what's important to the customer a bevy of smiling cabin attendants isn't high on the list. A reliable and cost-effective service has a much higher weighting than free newspapers, and onboard entertainment. They currently have the balance right and are attracting a good quantity of loyal, like-minded customers who have those same requirements from their airline. In this climate, I can only see them going from strength to strength." - Rachel Lane (Thompson, 2012, para17).

"The reason that Ryanair continually 'please' their customers is it has low customer expectations. Every time I board a Ryanair flight I don't care about the service or any lavish extras, that isn't the reason I booked - all I care about is the cheap price I have paid and arriving at my destination... end of. Therefore, when I arrive at my destination and have more money to spend as a result of the cheap flight, I'm happy. It surprises me when companies fail to understand why their customers aren't happy when they have customer expectations that don't align correctly to what their customers want or what they can offer. Get you customer 
expectations right and your customers will leave satisfied. Yiannis Maos (Thompson, 2012, para. 18).

\section{The Enigma of Consumer Behavior}

Despite a great deal of interest and resource investment, many basic questions in the area of consumer behavior remain enigmatic. Throughout various industries, customer service is considered paramount, especially in the highly competitive modern marketplace. It is intuitively assumed that delivery of good customer service will lead to customer satisfaction, which in turn will lead to customer loyalty and repurchasing behavior. Indeed, some research has confirmed the positive correlation between service quality and customer satisfaction (Moreno, 2014; Orel \& Kara, 2014) and furthermore, the relationship between customer satisfaction and positive purchasing intentions (Theodorakis, Alexandris, Tsigilis \& Karvounis, 2013) and intended customer loyalty (Kumar, Batista \& Maull, 2011).

In the real world of the competitive aviation industry, however, Ryanair blatantly and unapologetically thwarts this golden rule of business conduct, and yet remains one of the most successful and profitable airlines in the skies. Clearly, the equation for "success" is comprised of numerous complex variables, of which customer service/satisfaction does not stand alone in its influence on customer choice and overall business profitability. Equally clearly, Ryanair manages to get enough of these other variables "right" that it is not dependent upon customer service/satisfaction for its success. This paradox leads to two fundamental avenues of inquiry: 1) What is the true value of customer service in business success? Is it a necessary and/or sufficient condition? and 2) Would Ryanair be even more successful if they embraced the generally accepted principles of quality customer service?

\section{Epilogue - The End of the Runway for the Era of Bad Behavior?}

The year 2013 represented a fork in the road for Ryanair. In the aforementioned survey in Which? Magazine (2013), Ryanair was deemed to have "the worst customer service out of Britain's 100 biggest brands." While not a wholly new depiction, this time it was accompanied by financial and competitive losses in the marketplace. Ryanair suffered a $£ 28.7$ million loss in the final quarter of 2013. It marked the end of an era of their unique adversarial customer relationship management and ushered in a new philosophy that will be explored in a follow-up paper that covers the period from $2014-2018$.

\section{Hypotheses}

$\mathrm{Ha}_{1}$. Customers will award Southwest Airlines a significantly higher "overall ranking" than Ryanair. 
$\mathrm{Ha}_{2}$. Customers will rate Southwest Airlines significantly higher than Ryanair with regard to seat comfort, cabin service, food and value.

$\mathrm{Ha}_{3}$. A greater proportion of customers will recommend Southwest Airlines than Ryanair.

\section{Design}

The methodological design employed in this research is the Comparative Case Study. As described by Yin (2014) case studies represent a preferred method of research in situations where the main research questions are focused on determining the "how" and or "why" of a phenomenon and where the investigation focuses on a contemporary phenomenon in its real-world context. Druckman (2005) further prescribes this method for research that focuses on deep probes into cultural practices or behaviors of entities and with problems seeking causal explanations of variation between closely matched units of analysis. In this method, matched cases are chosen on the basis of similarities among certain characteristics with differences occurring in the variables under examination. The associated similarities and differences between Southwest and Ryanair were reviewed.

\section{Limitations}

The known limitations of this study include:

1. Southwest Airlines and Ryanair operate in different parts of the world. Southwest operates primarily in the United States and Ryanair operates in Europe. Differences in air traffic and culture between these two regions were not accounted for in this study.

2. The survey instrument was voluntary. Although insight can be gained by examining customer perceptions, any generalization beyond the survey respondents themselves is not recommended.

\section{Method}

This study used a survey research design to examine customer perception of two different airlines, Ryanair and Southwest Airlines. Skytrax has continuously measured customer perceptions on airline and airport quality since 1989. The organization is "dedicated to improving quality of the customer experience for airlines and airports across the world" (Skytrax, 2017a, para. 1). 


\section{Participants}

The cases chosen for this in-depth, focused case study represent two airlines in the low-cost carrier category - Southwest Airlines and Ryanair. While these two airlines differ in various characteristics (geographic location, pricing structure), they also have marked similarities (See Table 1) making them analogous for the purposes of this study. Both the similarities and differences were analyzed, and their implications discussed. Of particular interest to this study are the overall business models which espouse similar goals but very different (arguably diametrically opposed) methods of conducting business, specifically with regard to brand presentation, customer service, and the effects of each of these on the organizations' culture and business success.

\section{Survey Instrument}

The online survey instrument asked customers to state what airline they flew and give an overall ranking (1- poor to 10 - outstanding). The next four questions asked customers to rate their perception of customer services in the following areas: seat comfort, cabin service, food and value from 1 star (poor) to 5 stars (excellent). The last multiple-choice question customers answered was if they would recommend the airline and were given two options, a red $\mathrm{x}$ (would not recommend) and a green checkmark (would recommend). Survey respondents were then given an open-ended comment area in which to give the basis for their perceptions (Skytrax, 2017b; Skytrax, 2017c).

\section{Data Examined}

The survey responses examined were from the Skytrax database for both Ryanair and Southwest for the period of Jan 2012 to December 2013. This timeframe was chosen because of the different approaches used by Ryanair (low level of customer service - low expectation of service) and Southwest (high level of customer service - high expectation of service). Both airlines are low cost airlines, however, their different approaches to customer service is well known.

\section{Treatment of the Data}

Survey data were examined in three ways. First, ordinal responses from customers' survey results were used. These data were compared for the two independent groups (Ryanair customers n=165 and Southwest Airlines customers $\mathrm{n}=149$ ). With regard to "overall rating," customers would give a number from 1 (poor) to 10 (outstanding). Four questions that followed used a five-star rating scale (seat comfort, cabin service, food and value). The Mann-Whitney U statistic at $\alpha=.05$ was used to evaluate these data and test the first and second hypotheses in the study. 
The second form of examination were survey responses on whether Ryanair or Southwest customers would recommend the airline they had flown. These nominal data were tested using Chi Square $\alpha=.05$ to test the third hypothesis in this research (Gay, Mills, \& Airasian, 2006). Statistical results indicated how customers of the two different airlines felt about the service they received. However, researchers wanted to also investigate why people held their perceptions.

The third method in which data were examined focused on open ended responses customers wrote at the end of the survey. Researchers used NVivo software to examine a total of 314 customer comments. There were a similar number of responses for both carriers, 165 customer comments about Ryanair and 149 comments on Southwest Airlines. Ryanair and Southwest comments were initially reviewed separately. Researchers read and coded each response to allow trends to emerge. Once comments from both airlines were coded, researchers identified common categories between Ryanair and Southwest Airlines which could be directly compared (Gay et al. 2006).

\section{Statistical Results}

Statistical tests shown in the next three tables were used to evaluate the hypotheses in this study. Table 2 shows the analysis for the "Overall Ranking" customers gave to either Ryanair or Southwest Airline. 
Table 2

Overall Airline Ranking

\begin{tabular}{lccc}
\hline & Median Rank 1-10 & Value & p-value \\
\hline Ryanair $(\mathrm{n}=126)$ & 8 & & \\
\cline { 1 - 2 } Southwest $(\mathrm{n}=123)$ & 9 & 14985 & $.0228^{*}$ \\
\hline
\end{tabular}

Note. Data taken from Skytrack survey on Ryanair (2017b) and Southwest (2017c) survey for inclusive dates of Jan 2012-Dec 2013. Analyzed with Mann-Whitney U $\alpha=.05$

Southwest Airlines had a higher median rank than Ryanair with regard to overall airline ranking and that difference was statistically significant. These results support rejection of the null hypothesis of no difference in customer perception between the two carriers with regard to overall ranking on a 1 to 10 scale.

Table 3 shows the results from four separate questions survey respondents answered. Each question evaluated a separate category - seat comfort, cabin/staff service, food and value.

Table 3

Ratings for Seat Comfort, Cabin/Staff Service, Food and Value (1-5 stars)

\begin{tabular}{lllll}
\hline & Airline & Median Rank & Value & p-value \\
\hline Seat Comfort & Ryanair $(\mathrm{n}=160)$ & 3 & & \\
& Southwest $(\mathrm{n}=143)$ & 4 & 21072 & $<0.0001^{*}$ \\
\hline Cabin/Staff Service & Ryanair $(\mathrm{n}=160)$ & 3 & & \\
& Southwest $(\mathrm{n}=145)$ & 4 & 20660 & $<0.0001^{*}$ \\
\hline Food & Ryanair $(\mathrm{n}=108)$ & 3 & & \\
& Southwest $(\mathrm{n}=124)$ & 4 & 10229 & $<0.0001^{*}$ \\
\hline Value & Ryanair $(\mathrm{n}=160)$ & 3 & & \\
& Southwest $(\mathrm{n}=146)$ & 4.5 & 21924 & $0.0004^{*}$ \\
\hline
\end{tabular}

Note. Data taken from Skytrack survey on Ryanair (2017b) and Southwest (2017c) survey for inclusive dates of Jan 2012-Dec 2013. Evaluated with Mann-Whitney U $\alpha=.05$

Customers rated Southwest Airlines significantly higher than Ryanair in the areas of seat comfort, cabin/staff service, food and value. These results support rejection of the null hypothesis of no difference in customer perception between the two carriers in all four categories. 
The final statistical analysis was conducted for the question "Would you recommend this airline?" Results from this question follow in Table 4.

Table 4

Results for "Would you recommend this airline?"

\begin{tabular}{llllll}
\hline & Yes & No & Total & Value & Chi Square \\
\cline { 1 - 4 } Ryanair & 71 & 94 & 165 & & \\
\cline { 1 - 4 } Southwest & 93 & 56 & 149 & & \\
\cline { 1 - 5 } Totals & 164 & 150 & 314 & 11.3972 & $0.0006^{*}$ \\
\hline
\end{tabular}

Note. Data taken from Skytrack survey on Ryanair (2017b) and Southwest (2017c) survey for inclusive dates of Jan 2012-Dec 2013. Analyzed with Chi Square contingency table, $\alpha=.05$ using StatDisk (Triola, 2013).

Customers rated Southwest Airlines significantly different (higher) than Ryanair on the question "would you recommend this airline?" Slightly more than $62 \%$ of Southwest customers indicated they would recommend Southwest. Only $43 \%$ of Ryanair customers would recommend using Ryanair. The results shown in Table 4 support rejection of the null hypothesis of no difference in customer perception between the two airlines on this question.

\section{Recurring Themes from Open Area Comments}

Survey responses were analyzed using NVivo software to identify significant trends in open area comments. Ryanair $(n=165)$ and Southwest Airlines $(\mathrm{n}=149)$ customer responses were examined for significant trends. Some responses involved several different comments on multiple themes and/or several areas within the same major theme. Researchers coded 367 Ryanair and 328 Southwest Airline customer comments into the themes or sub-themes shown in Table 5 below. 
Table 5

Overview of Ryanair and Southwest Airline Customer Themes Ranked by Percentage of Comments

\begin{tabular}{|c|c|c|c|}
\hline \multicolumn{2}{|l|}{ Ryanair } & \multicolumn{2}{|l|}{ Southwest Airlines } \\
\hline Theme & No. & Theme & No. \\
\hline Customer Service - Poor & $\begin{array}{l}195 \\
(53 \%)\end{array}$ & Customer Service -Poor & $\begin{array}{l}94 \\
(29 \%)\end{array}$ \\
\hline $\begin{array}{ll}\text { - } & \text { Inefficient or } \\
\text { Unwelcome Processes } \\
121(33 \%) \\
\text { - } \quad \text { Discourteous or } \\
\text { Unfriendly Service } \\
74(20 \%)\end{array}$ & & $\begin{array}{ll}\text { - } & \text { Inefficient or } \\
\text { Unwelcome Processes } \\
71(22 \%) \\
\text { - } \quad \text { Discourteous or } \\
\text { Unfriendly Service } \\
23(7 \%)\end{array}$ & \\
\hline Customer Service - Good & $\begin{array}{l}48 \\
(13 \%)\end{array}$ & Customer Service - Good & $\begin{array}{l}86 \\
(26 \%)\end{array}$ \\
\hline Efficient & $\begin{array}{l}40 \\
(11 \%)\end{array}$ & Efficient & $\begin{array}{l}54 \\
(16 \%)\end{array}$ \\
\hline Value & $\begin{array}{l}39 \\
(11 \%)\end{array}$ & $\begin{array}{l}\text { Cabin Configuration and } \\
\text { Cleanliness - Good }\end{array}$ & $\begin{array}{l}39 \\
(12 \%)\end{array}$ \\
\hline $\begin{array}{l}\text { Cabin Configuration and } \\
\text { Cleanliness - Poor }\end{array}$ & $\begin{array}{l}24 \\
(7 \%)\end{array}$ & Value & $\begin{array}{l}38 \\
(12 \%)\end{array}$ \\
\hline $\begin{array}{l}\text { Cabin Configuration and } \\
\text { Cleanliness - Good }\end{array}$ & $\begin{array}{l}21 \\
(6 \%)\end{array}$ & $\begin{array}{l}\text { Cabin Configuration and } \\
\text { Cleanliness - Poor }\end{array}$ & $\begin{array}{l}17 \\
(5 \%)\end{array}$ \\
\hline
\end{tabular}

Note. Data taken from Skytrack survey on Ryanair (2017b) and Southwest (2017c) survey for inclusive dates of Jan 2012-Dec 2013. Data were coded into NVivo software Version 11 (2017). Percentages are expressed in parentheses under the actual number of coded responses indicating number of comments in a specific theme or sub-them divided by the total number of coded comments for the airline. Customer service is broken out into two sub categories; (1) inefficient or unwelcome processes and (2) discourteous or unfriendly service.

\section{Ryanair Themes}

Sixty-eight percent of comments that were coded for Ryanair survey responses indicated that the airline delivered a poor level of customer service. Customer service was broken out in to two areas; inefficient or unwelcome processes and discourteous or unfriendly service. Most of these comments involved inefficient or unwelcome process (33\% of all Ryanair comments noted). Customers complained about expensive luggage fees (7\%), high fees to print boarding passes (customers who did not print out boarding passes prior to arriving at the airport 
were charged 70 Euros each - $7 \%$ of Ryanair comments) and poor check-in and boarding processes (6\%).

One Ryanair passenger commented: "They offer a cheap up-front cost because they look for any and every way to charge you on other items. No boarding passes printed? 70 Euros each." Another customer commented: "My wife and I flew to Fuerteventura with Ryanair 2 weeks ago. We will never travel with them again. We had to pay $£ 140$ to have 2 sheets of paper printed by the rudest person you could meet." Regarding the check-in and boarding procedure a Ryanair passenger wrote:

My girlfriend and I arrived early and were treated to a lengthy queue at Stansted before a manic rush for seats ensued. Does the company not realize that not allocating seats will cause this? It flares up tempers and causes the whole plane load of passengers to be angry from the start.

A passenger commented on the general feel of flying on Ryanair: "Always looking for a new way to con passengers into falling foul of a regulation so they can extort money to bring their cheap fares in to line with the proper airlines." Another commented: I thought that I was booking a budget airline and accept all that entails however as the final cost once all the 'extras' such as luggage were added I finally paid over 2500 for my family's seats and may as well have gone on a better airline. Nineteen complaints (5\%) stated that Ryanair were too focused on selling items, food and drink to customers for the entire flight. One of those comments read: "The crew on both legs were surly. All they did on a 2.5-hour flight was to try and sell things." Three percent of Ryanair customers stated food and drink prices were too high. Discourteous or unfriendly service was noted in 74 comments representing $20 \%$ of all comments coded for Ryanair customers.

Ryanair also had a number of customers who thought they provided good customer service. Forty-eight of the 367 comments coded (13\%) indicated Ryanair did a good job in taking care of its customers. One such comment read: staff are courteous at all times." Another stated: "Staff were friendly and efficient." A firsttime passenger wrote: "First time with Ryanair won't be the last. From the online booking priority boarding getting on getting off the whole experience was brilliant."

Themes of efficiency and value were both cited by $11 \%$ of Ryanair comments mostly for on-time take offs and arrivals and low prices. Cabin cleanliness and configuration received 45 comments which were relatively evenly split between stating Ryanair's cabins were clean or had comfortable seats $(7 \%)$ and customers who stated the seats were uncomfortable, and there was a lack of onboard storage room or dirty cabins $(6 \%)$. 


\section{Southwest Airline Themes}

Twenty-nine percent of comments that were coded from Southwest Airlines survey responses indicated that the airline gave a poor level of customer service. As discussed earlier, customer service was broken out in to two areas; inefficient or unwelcome processes and discourteous or unfriendly service. Most comments involved inefficient or unwelcome process (22\% of all Southwest Airlines comments noted). Almost half of the complaints regarding inefficient processes, (10\% of Southwest responses overall), concerned poor handling of flight delays. One such comment was:

I was actually sitting there (at the gate) when the second text came telling me of the delay until 6.20pm. At 6.10 I got up and walked down to my gate. When I arrived I discovered that the plane had actually departed at 5.50 before I received the second text.

Other issues noted included poor check in and boarding process. A Southwest Airlines passenger commented: "The open seating is like a mad zoo. No control. People pushing. It is the worst possible way I have ever seen to board a plane." Another wrote:

....Bags fly free but at SW passengers are just another bag. You pay good money to stand in a cattle chute...maybe have to ask someone's permission to sit in a seat if you are not lucky enough to get a good boarding position.

Discourteous or unfriendly service complaints were noted in $7 \%$ of all items coded for Southwest Airlines customers. Southwest Airlines also had a number of customers who thought they provided good customer service. Eighty-six of the 328 comments coded (26\%) indicated Southwest Airlines did a good job in taking care of its customers. Broken down further, 45 comments (14\%) cited courteous friendly and professional staff/aircrew, $25(8 \%)$ commented on service oriented processes such as the check in procedure or open-seating boarding and 16 comments $(5 \%)$ stated flight delays were handled well. Typical of passenger comments was: "Both planes were full but it was organized and ran smoothly. Excellent value (free baggage etc.). I would take Southwest again just based on the employee attitudes."

Efficiency was cited by $16 \%$ of southwest Airline comments relating to ontime performance, check in and boarding processes. Southwest customers commented that cabin cleanliness, configuration, and/or seats were good (12\%), a much higher rate than customers who complained about dirty cabins or uncomfortable seats (5\%). Lastly, value, usually expressed as low prices, was noted in $12 \%$ of Southwest customer comments. A customer wrote: "I will likely continue flying with Southwest Airlines because they do not charge as many fees 
and generally speaking do their job with greater efficiency than any other domestic US carrier."

\section{Discussion}

Differences in the perception of customer service between the two airlines were noted despite preconceived notions of service. Southwest customers ranked seat comfort, cabin/staff service, food, and overall value significantly higher than Ryanair customers. Additionally, Southwest customers gave Southwest a higher overall ranking and would be more willing to recommend their airline than Ryanair customers. All results were statistically significant. The comparison between Ryanair and Southwest Airlines shows two low cost airlines that took two distinctly different approaches to customer service. Southwest Airlines promised good customer service. Ryanair by contrast, did not. The statistical results from the survey verified that these approaches were felt by customers indicating what customers felt. Open area survey results showed why people held their perceptions of the two airlines.

Ryanair customers took a very negative view of processes viewed as difficult to deal with if not mean spirited. The high percentages of negative comments on inefficient or unwelcome processes (33\%) and unfriendly service (20\%) indicate that customers desired to be treated fairly and politely, even if they were expecting a low level of customer service. Most of the comments in this area focused on check-in seating policy, paying to print off boarding passes, and selling items throughout the flight. Conversely, Southwest Airlines was at the opposite end of the low-cost carrier, high-customer service expectation spectrum. Some Southwest customer comments complained about processes (22\%) but only $7 \%$ complained about discourteous or unfriendly service.

Commonalities in customer comments between the two airlines were present. The top three themes - poor customer service, good customer service, and efficiency - were in the same order for both airlines. The value theme was also ranked at $11 \%$ for Ryanair and $12 \%$ for Southwest Airlines. Within the value theme, customer comments were passionate about price which was a big factor in deciding which airline to fly. Customers from both airlines made negative comments about seat comfort at a similar $3.5 \%$ rate. Southwest customers however made a higher percentage of positive comments on seat comfort $(8 \%)$ than Ryanair customers $(2.5 \%)$.

Differences between the two airlines noted were that Ryanair's procedures were viewed more negatively than Southwest $33 \%$ to $22 \%$ respectively and Ryanair was perceived as giving discourteous or unfriendly service (noted in 20\% of comments by Ryanair customers). It is interesting to note that $3 \%$ of Ryanair customers commented in support of the airline's rules and procedures arguing that 
customers should know that they need to print out boarding passes in advance, keep the size of their carry-on bags small and not buy items, food, or drink viewed as expensive while on the aircraft. One Ryanair customer emphasized: "People need to remember they get what they pay for - you pay cheap you get cheap and that includes staff crew seats food etc. Do not moan just follow the rules." Another Ryanair customer echoed: "People get to the check-in and have to start unpacking cases because they can't be bothered to weigh their luggage. Ryanair is the cheapest not the best...most of the problems I have seen are caused by the passengers themselves."

Lack of space for handbags on board the aircraft and dirty cabins were also cited in more Ryanair comments. Southwest customers also made slightly more comments $16 \%$ noting efficient airline operations than Ryanair (11\%).

\section{Conclusions}

While these results were in line with the general intuitive expectations - a business that focuses on delivering quality customer service will be ranked higher on that measure than one that does not - the data also indicated some surprising paradoxes. Given these diametrically opposed approaches to consumer engagement, it is surprising that $29 \%$ of the comments indicated that Southwest delivered poor customer service, and, equally surprising that $13 \%$ of the comments indicated that Ryanair provided good customer service. Additionally, while the differences between the results for the two airlines were statistically significant, they were not necessarily as pronounced as might be anticipated, given the extensive differences between the philosophies and operating practices.

These unexpected results can certainly be attributed to the complexity (and often ambiguity) of the nature of customer service. Delivering quality customer service is not an exact science and catering to the specific needs of each and every customer in each and every instance is clearly not possible. Additionally, the researchers theorize that expectation confirmation theory (also referred to as Expectation Confirmation Theory) may play a role in the observed customer ratings. This theory contends that satisfaction is dependent upon the confirmation (or disconfirmation) of expected outcomes, such as with a product or service (Oliver, 1977, 1980). In this case, the theory would posit that Ryanair would be judged less stringently on customer service due to the low initial expectations. Conversely, Southwest would be judged more rigorously on the same criteria, based on its initial high expectations. Satisfaction then, represents a subjective mental judgment based on the perceived discrepancy between an anticipated outcome and the actual experience, rather than on a clear and consistently applied standard 


\section{Recommendations}

A natural recommendation resulting from this study would be for Ryanair to consider implementing a revised customer service program. It should be noted that Ryanair initiated such a program 2014. Future research will compare Ryanair customer comments during the periods of 2012-2013 and 2015-2018 to determine if these efforts improved customer perception of their airline and if/how that, in turn, affected perceived brand personality and profitability. 


\section{References}

Anderson, E.W., Fornell, C., \& Lehmann, D.R. (1994). Customer satisfaction, market share and profitability. Journal of Marketing, 56(July), 53-66.

Bennett, R. D., \& Craun, J. M. (1993). The airline deregulation evolution continues: The Southwest effect. Washington, DC: US Department of Transportation.

Brown, J. (2016, January 13). 30 intelligent Herb Kelleher quotes. Retrieved from https://addicted2success.com/success-advice/30-intelligent-herb-kelleherquotes

Czaplewski, A., Ferguson, J., \& Milliman, J. (2001). Southwest Airlines: How internal marketing pilots success. Marketing Management, 10(3) 14-17.

Daily Telegraph. (2012, September 5). The most wonderfully offensive quotes from Ryanair boss Michael O'Leary. Retrieved from www.telegraph.co.uk

Druckman, D. (2005). Doing research. Thousand Oaks, CA: Sage Publications.

Economist. (2007, August 23). Snarling all the way to the bank. Retrieved from www.economist.com

Friedberg, J., \& Friedberg, K. (1997). Nuts! Southwest Airlines' crazy recipe for business and personal success. New York, NY: Broadway Books

Gay, L. R., Mills, G. E., \& Airasian, P. W. (2006). Educational research: Competencies for analysis and applications. (8th ed.). Upper Saddle River, NJ: Pearson Education, Inc.

Gould, M. (2018, August 23). Ryanair ignores the link between customer experience and employee experience. Retrieved from www.business2community.com

Kumar, V., Batista, L., \& Maull, R. (2011). The impact of operations performance on customer loyalty. Service Science, 3(2), 158-171.

Luo, X., \& Homburg, C. (2007). Neglected outcomes of customer satisfaction. Journal of Marketing, 71(2):133-149.

Magrath, A. (2014, October 31). Ryanair named second-worst brand in the WORLD for customer service. Retrieved from: www.dailymail.co.uk

McClure, G. (2013, December). Polyester airlines: Ryanair vs. Southwest. Retrieved from: www.flightfox.com

Menza, J. (2013, June 24). We're Europe's Southwest Airlines. CNBC. Retrieved from https://www.cnbc.com/id/100839583

Michaels, D. (2000, September 6). Inspired by U.S.'s no-frills Southwest, Ryanair reshapes European travel. The Wall Street Journal. Retrieved from www.wsj.com.

Moreno, F. C. (2014). Effect of service quality and perceived value on satisfaction: An exploratory study of basketball spectators. Retrieved from 
http://www.easm.net/download/2008/94fa15bd4a0e8475124818ac66f966e 1.pdf

Oliver R. L. (1977). Effect of expectation and disconfirmation on postexposure product evaluations - An alternative interpretation. Journal of Applied Psychology, 62(4), 480.

Oliver R. L. (1980). A cognitive model of the antecedents and consequences of satisfaction decisions. Journal of Marketing Research, 17(4), 460.

Orel, F. D., \& Kara, A. (2014). Supermarket self-checkout service quality, customer satisfaction, and loyalty: Empirical evidence from an emerging market. Journal of Retailing and Consumer Services, 21(2):118-129.

Ozcelik, G., \& Findikli, M. (2014). The relationship between internal branding and organizational citizenship behavior: The mediating role of personorganization fit. Retrieved from https://ac.elscdn.com/ S1877042814051763/ 1-s2.0-S1877042814051763-main.pdf? _tid=4c1d1a80-62e6-4105-b1cc-951509b141a6\&acdnat $=1549851202 \_6 \mathrm{~d} 179 \mathrm{fdeb} 32658682 \mathrm{fbee} 3205852 \mathrm{ece} 1$

Porter, L. (2014, August 28). Ryanair: The truth about the airline's customer services department. Retrieved from telegraph.co.uk

PR Newswire. (2018, January 19). Southwest Airlines again among FORTUNE's top 10 world's most admired companies. Retrieved from www.prnewswire.com

Schleckser, J. (2018). Why Southwest has been profitable 45 years in a row. Inc. Retrieved from https://www.inc.com/jim-schleckser/why-southwest-hasbeen-profitable-45-years-in-a-row.html

Skytrax. (2017a). Quality is our Journey. Retrieved from http://skytraxresearch.com/

Skytrax. (2017b). Ryanair customer reviews. Retrieved from http://www.airlinequality.com/airline-reviews/ryanair/

Skytrax. (2017c). Southwest Airline customer reviews. Retrieved from http://www.airlinequality.com/airline-reviews/southwest-airlines/page/47/

Smith, O. (2013, September 19). Ryanair 'worst' brand for customer service. Retrieved from www.telegrpah.co.uk

Southwest Airlines. (2018). About SWA. Retrieved from https://www.southwest.com/html/about-southwest/index.html

Spreng R. A, MacKenzie, S. B., \& Olshavsky, R. W. (1996). A reexamination of the determinants of consumer satisfaction. Journal of Marketing, 60(3), 15 .

The Courier-Journal. (2000, September 12). Michael O'Leary borrowed cues from Southwest. The Courier-Journal from Louisville, Kentucky, p. 46.

Theodorakis, N. D., Alexandris, K., Tsigilis, N., \& Karvounis, S. (2013). Predicting spectators' behavioral intentions in professional football: The 
role of satisfaction and service quality. Sport Management Review, 16(1), 85-96.

Thompson, B. (2012, March 26). If the customer experience is so important, how do you explain the success of Ryanair? Retrieved from www.customerthink.com

Webb-Morgan, M. (2017, February 22). Southwest Airlines: A case study in great customer service. Retrieved from: www.business.com

Which? (2013, 19 September). Which? reveals best and worst brands for customer satisfaction. Retrieved from www.which.co.uk

Yeung, M. C. H., Ging, L. \& Ennew, C. T. (2002). Customer satisfaction and profitability: A reappraisal of the nature of the relationship. Journal of Targeting, Measurement and Analysis for Marketing, 11(1), 24-3.

Yin, R. K. (2014). Case study research: Design and methods (5th ed.). Los Angeles, CA: Sage. 


\section{APPENDIX A}

\section{Southwest Airlines Sample Advertising}

(www.southwest.com)

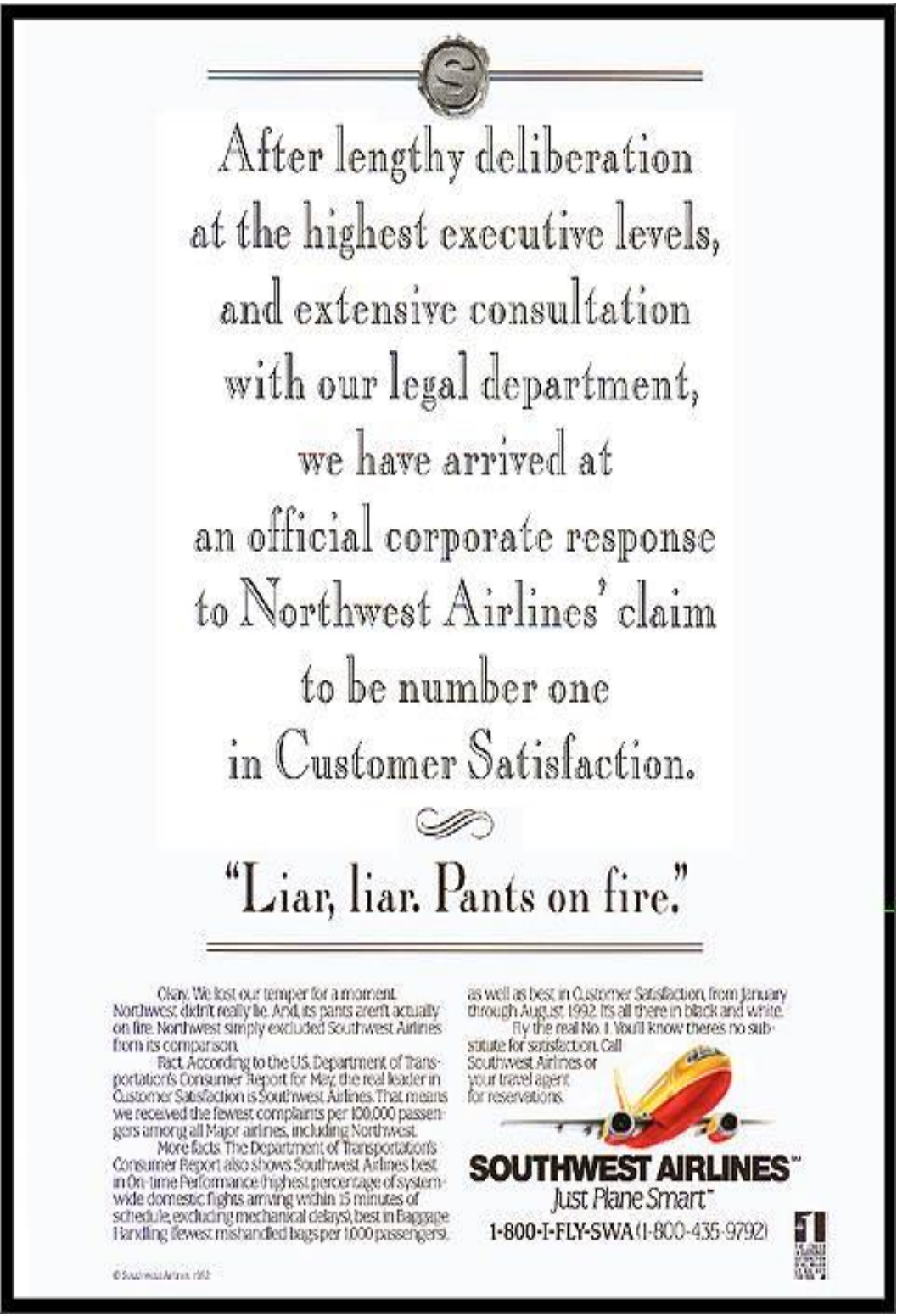




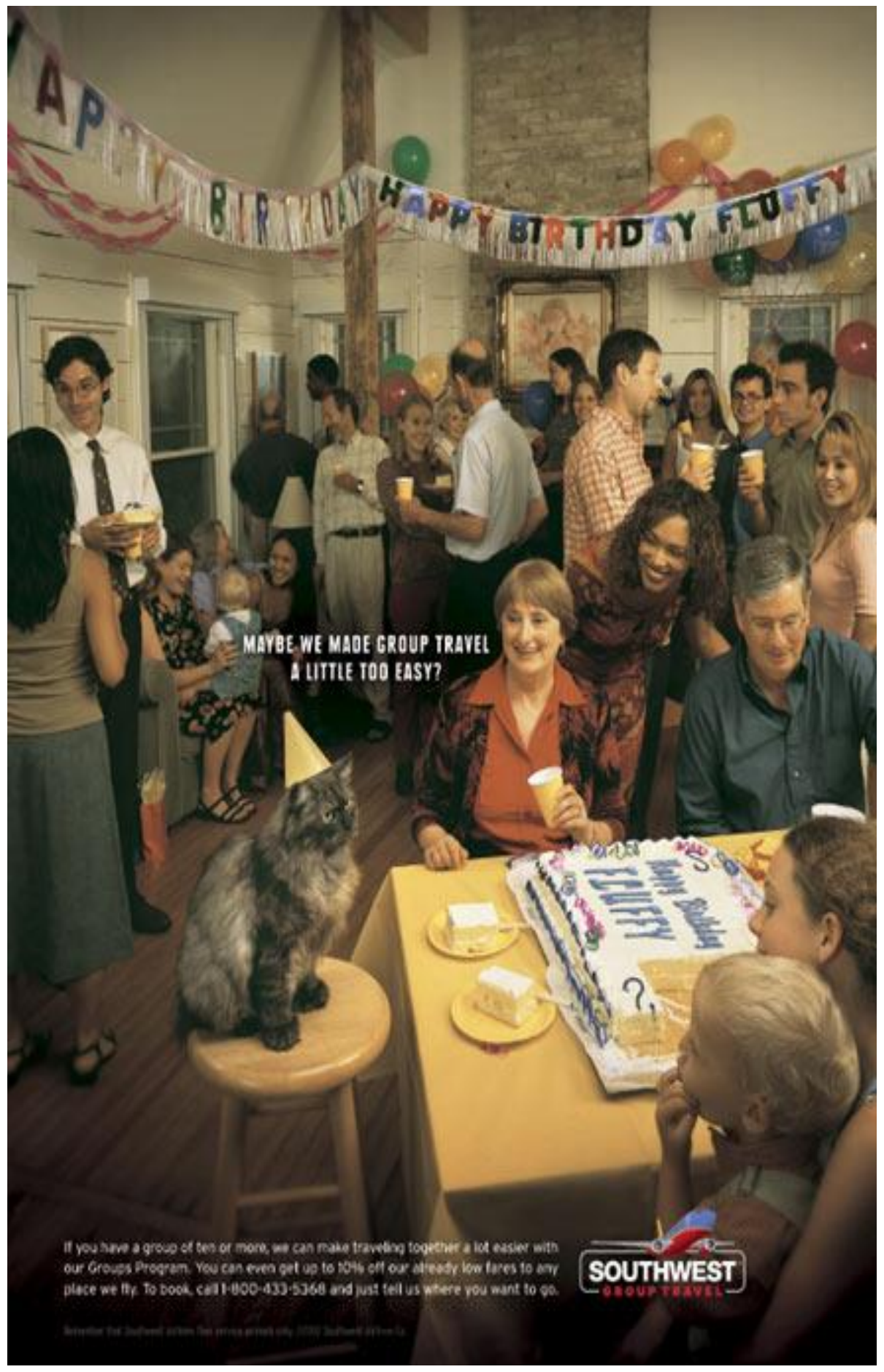


International Journal of Aviation, Aeronautics, and Aerospace, Vol. 6 [2019], Iss. 2, Art. 4

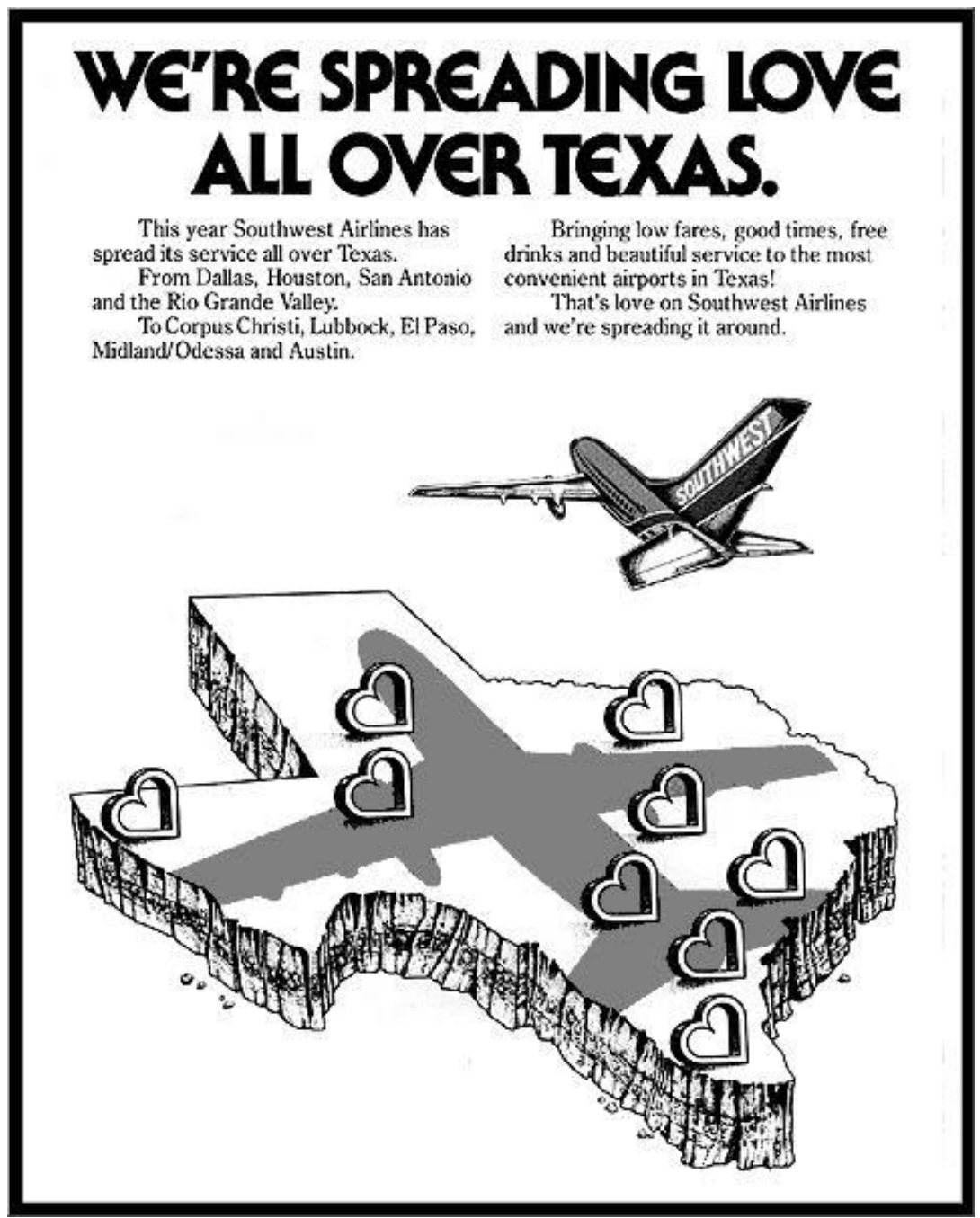




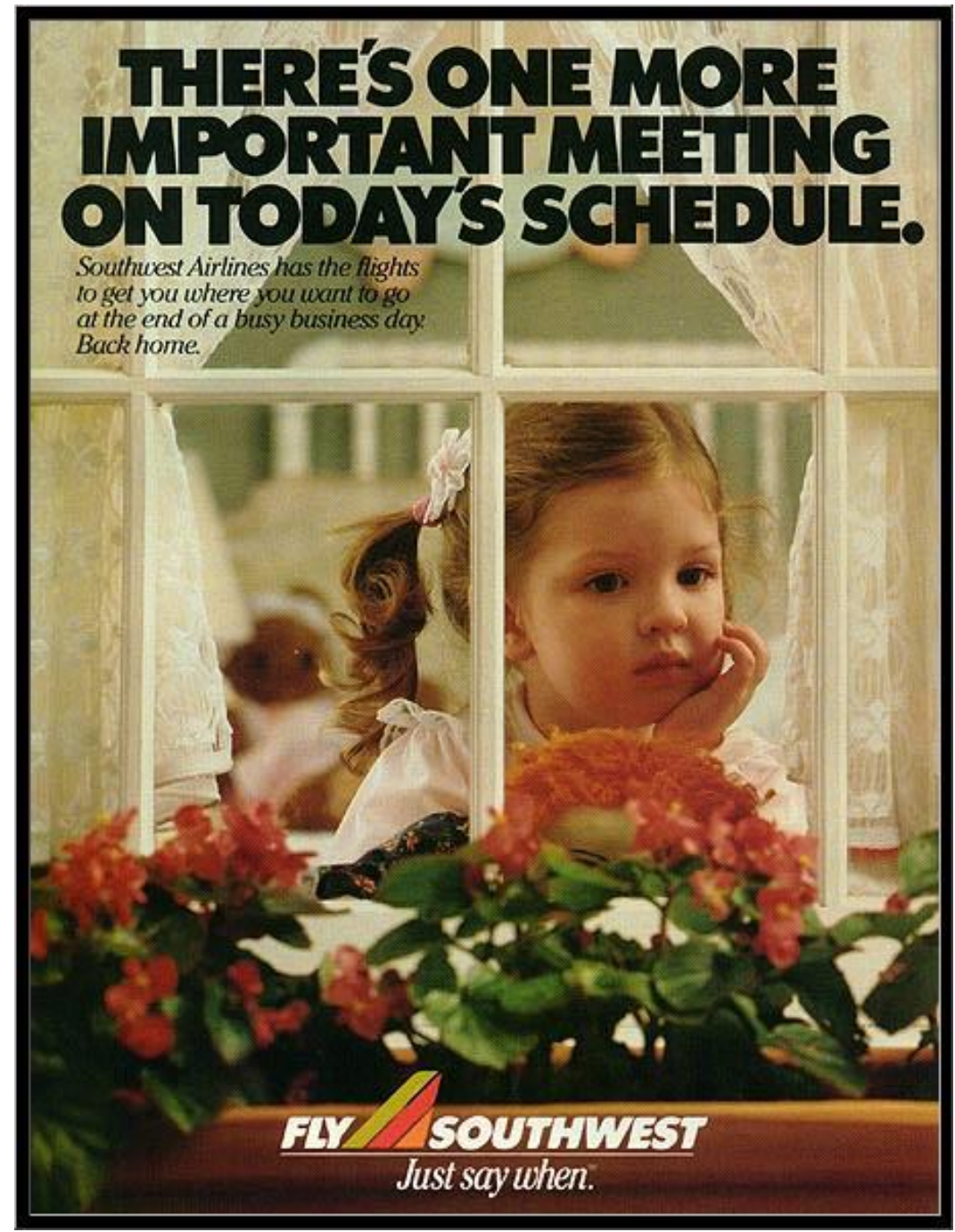


International Journal of Aviation, Aeronautics, and Aerospace, Vol. 6 [2019], Iss. 2, Art. 4

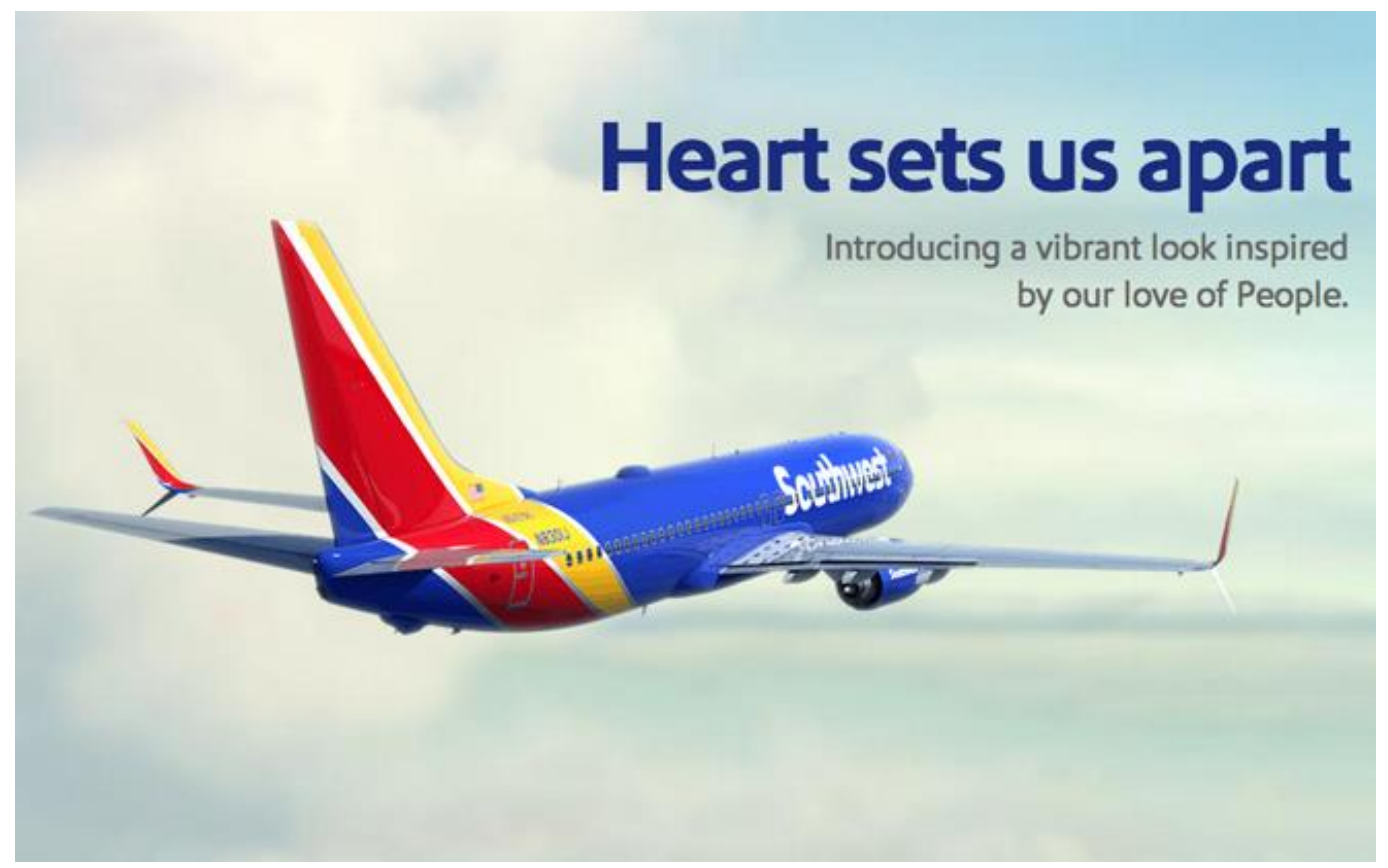




\section{Ryanair Sample Advertising}

(www.ryanair.com)

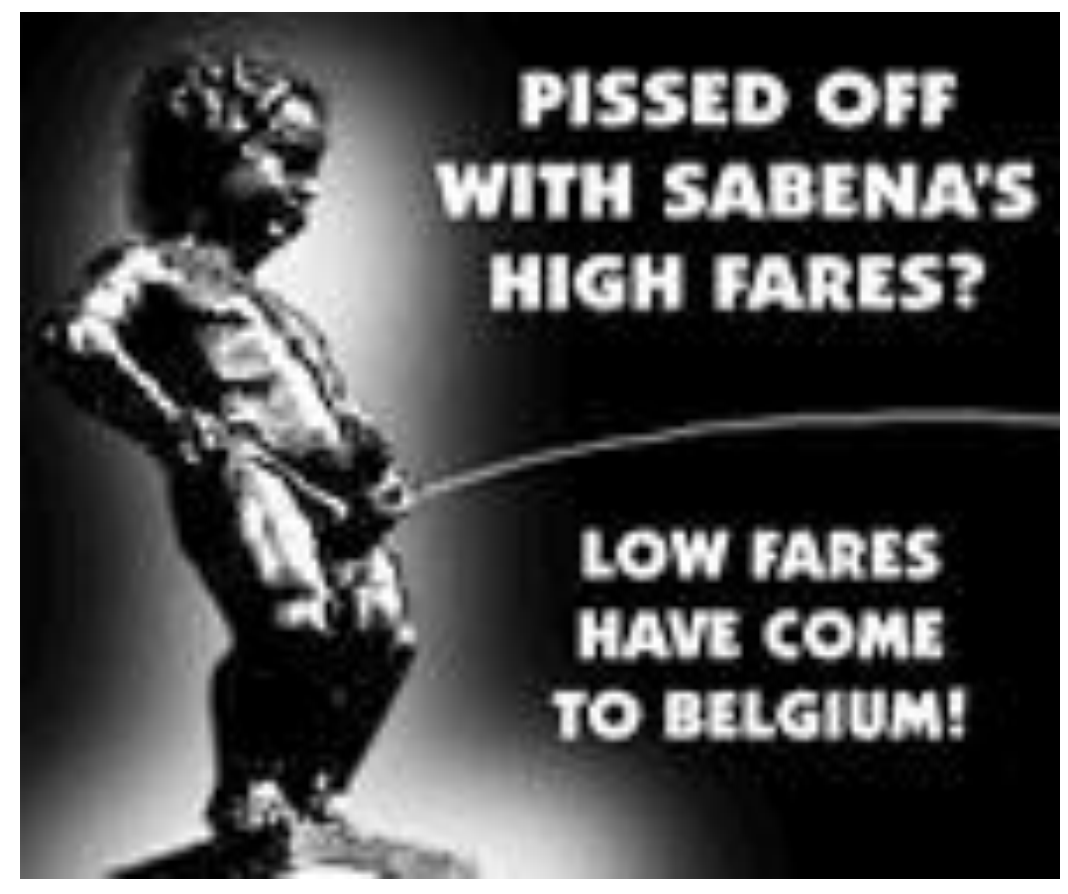




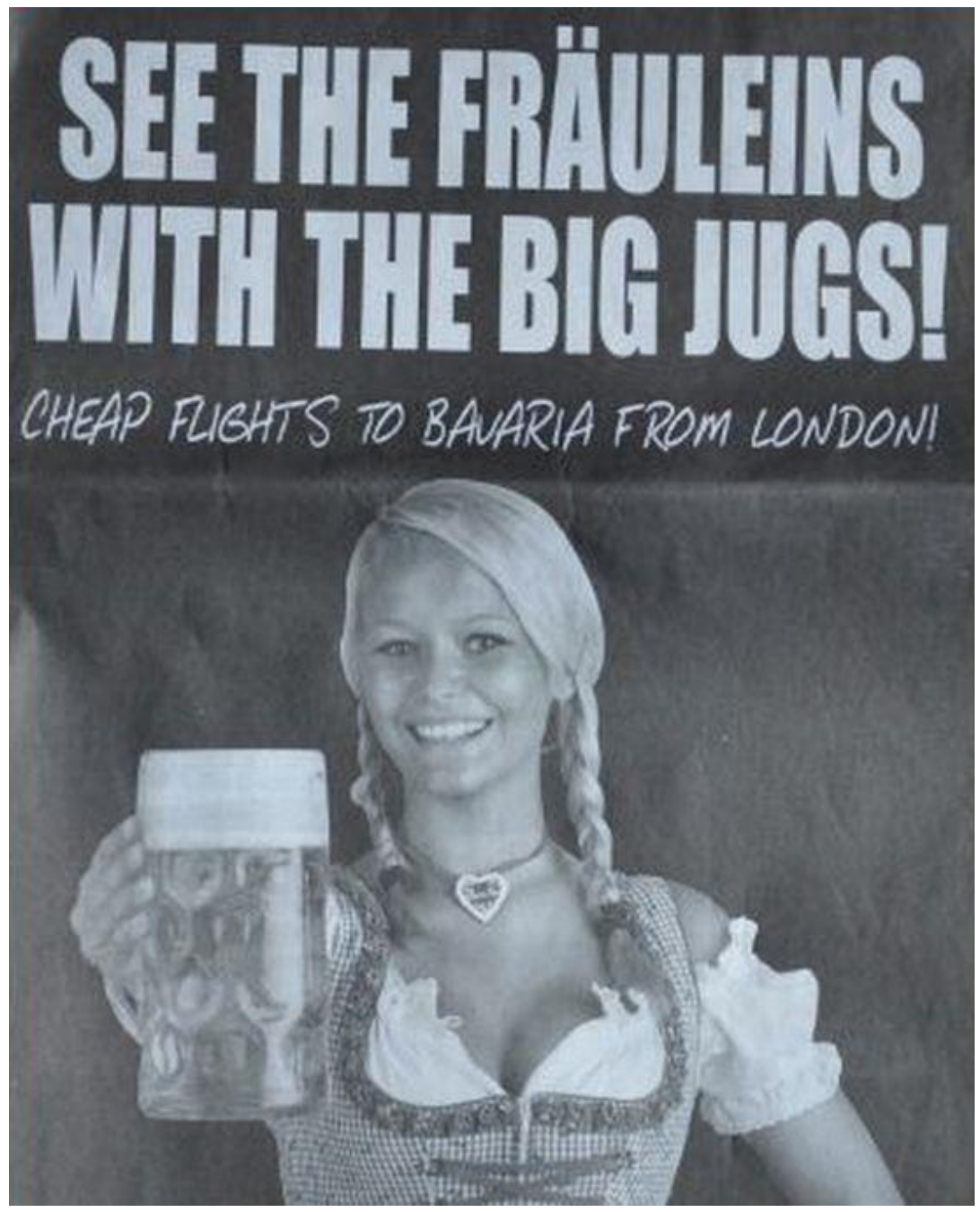




\section{ADVERTISEMENT}

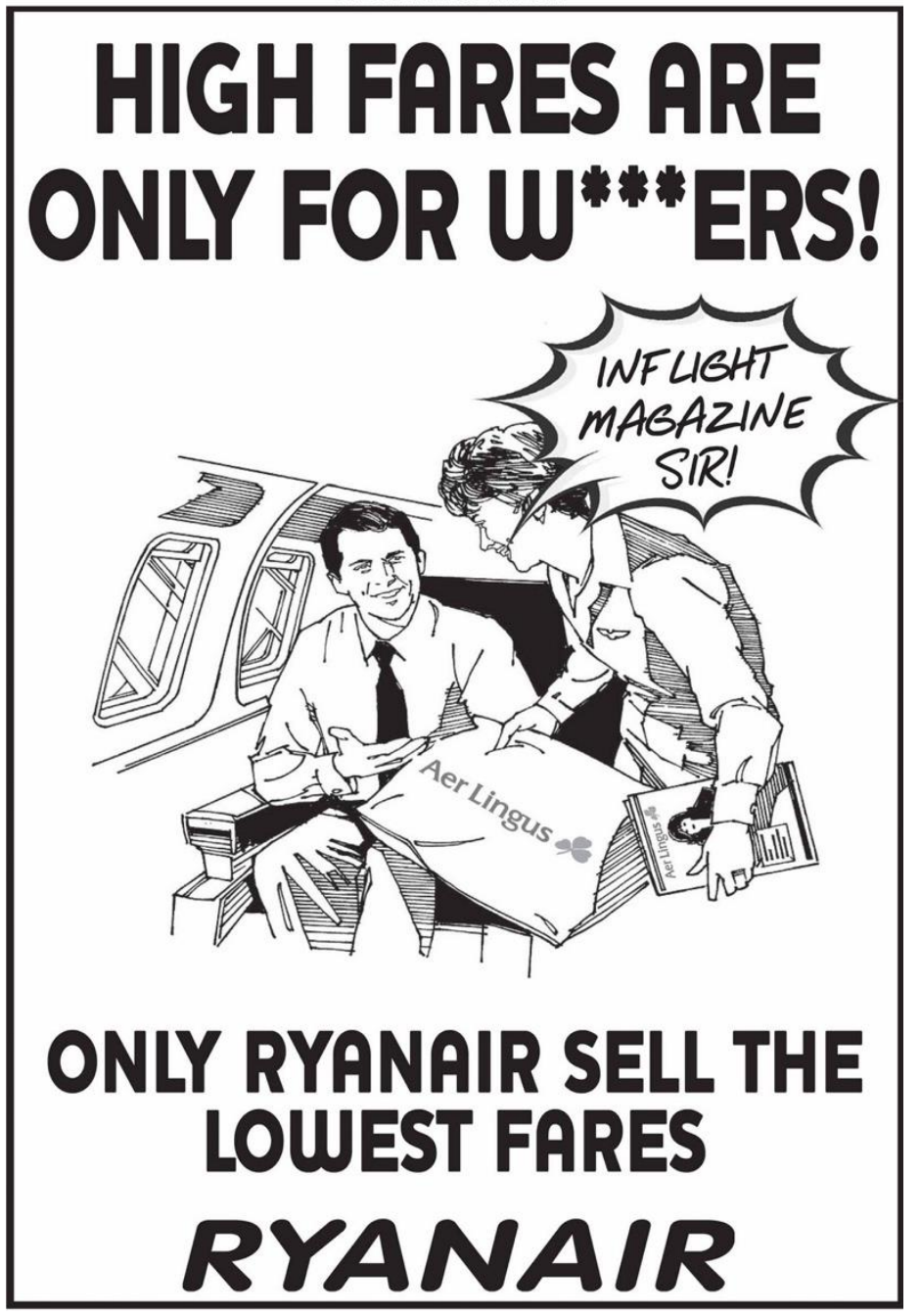

